\title{
Freedom of belief in the light of Maqasid al-shariah: Special reference to Sri Lanka
}

\author{
Najimudeen Mohamed Rishard ${ }^{l}$, Mohamed Mohideen Nayeem ${ }^{1}$, Muhaimin Sulam $^{1}$ \\ ${ }^{1}$ Department of Management and Humanities, Universiti Teknologi PETRONAS, 32610 Bandar Seri Iskandar, Perak, \\ Malaysia
}

\begin{abstract}
Concept of maqasid al-shariah (purposes of Shariah) is being re-interpreted in order to confront modern challenges and questions. This research analyses how the predominant segment of maqasid al-shariah, Protection of Religion, has been interpreted by modern scholars in a conflicting terminology as 'freedom of belief' and how they discuss the misapprehended texts which relate to the topic. Research focuses on applying the modern concept of freedom of belief which is one of the universal values, into Muslim majority countries as well as Sri Lanka where Muslims are a minority. A Special consideration has been specified on freedom of belief in Sri Lanka's constitution and its implementation. Qualitative data, mostly secondary data, has been used in this study. Data were collected from literary books, journal articles and internet sources. This research finds out that Sri Lanka in particular, a number of Muslim minority countries in general are healthier than several Muslim majority countries, especially Middle East countries, in practicing freedom of belief.
\end{abstract}

Key Words: Freedom of belief, Protection of religion, Maqasid al-shariah, Sri Lanka

\section{Introduction}

Maqasid al-shariah is a philosophy and it was implemented by the last messenger and his companions. A Number of prophetic narrations indicate that the companions of the messenger did not apply the 'apparent meaning' of his instructions (Auda, 2008). A famous incident of 'Banu Quraiza' was one of the transparent exemplifications for the above argument. The Second Khalifa Omar preferred to apply certain intent or purpose of text in his various decisions and judgments. After every battle he decided to distribute only one fifth of the conquered lands among the soldiers intending to enrich the public trust and achieve fairness amongst soldiers (Ibn Rushd, 2000).

After the era of the companions, traditional Imams applied some reasoning methods like Al-qiyas, Al-istihsan and Al-maslaha. Particularly, Abu Hanifah and Malik in their various legal opinions went beyond apparent meaning and gave their greatest possible effort to find out the cause or purpose of the text. But the maqasid terminology had not been used by Imams until the final phase of the 3rd Islamic century. In between 3rd to 5th Islamic centuries, some scholars paid their attention to maqasid al-shariah and they also had some publications in this regard (Raisuni, 2013). Between fifth to eight centuries, maqasid was drafted as a philosophy. The maqasid concept further developed and reached its matured stage in the 8th Islamic century.

After al-Shathibi, no proper efforts were put forward to enrich it until the modern Islamic renewal (Raisuni, 2013). Fortunately, Ibn al-Ashur was considered to be the first modern scholar to reopen the door for maqasid concept, who understood the significance of the maqasid in general and significance of al-Shathibi's tremendous and dynamic role in this subject in particular. He started to teach it in universities and academic forums. Furthermore, he was able to renew the maqasid thought in order to find solutions for modern problems and challenges. He included values such as equality and freedom in maqasid al-shariah (Raisuni, 2013).

Some other modern scholars tried to broaden the scope of the five traditional maqasid. For instance, Rashid al-Rila suggested to include reform and women's right in the theory of maqasid (Rila, 2010), Muhammad AlGazaly added justice and freedom to the pre-modern five maqasid (Atiya, 2008), and Taha Jabir al-Alwani added the concept of developing civilization on earth (Alwani, 2010).

The Maqasid philosophy is being reformed by contemporary Islamic scholars currently. They are completely involved in moving the philosophy of maqasid from a theoretical frame to a practical solution. Moreover, some

\footnotetext{
*Corresponding author: nm.rishad1985@gmail.com
} 
activists and politicians try to employ concept of maqasid in their social and political reformist projects (Rane, 2015). Their strategies and approaches in the nation building process using maqasid al-shariah are highly welcomed and appreciated by Muslim majority countries as well as the western countries. Furthermore, maqasid al-shariah is applied in other fields like economic, health, environment and social development (Deuraseh, 2012).

\section{Materials and Methods}

This study is descriptive and interpretive and mainly uses secondary data collected from sources such as research journals, reports from research centres and online resources. The data analysis used in this study is carried out qualitatively based on text. This research tries to apply modern interpretation of first segment of maqasid into contemporary world. Special attention has been paid on Sri Lanka's constitution and its application.

\section{Literature Review}

\subsection{Modern interpretation on Protection of Religion}

Traditional Islamic scholars used 'preservation' and 'protection' in their writings when they described maqasid al-shariah. In contrast, contemporary scholars have developed traditional maqasid terminologies according to modern challenges and problems. They use new terminologies like 'Rights' and 'Development' despite the opposition of few other jurists regarding these terminologies (Auda, 2007).

Ibn al-Ashur was one of the first most renowned modern-era scholars to open the door for re-interpreting the 'Theory of maqasid' in general and 'Theory of protection of religion' in particular. In previous periods scholars like Al-Juwaini used the terminology 'protection of Religion'. In modern days Ibn al-Ashur put forward a dramatically different concept for the word 'Hifl al-deen'. He preferred to use different terminologies such as 'Freedom of faith' and 'Freedom of belief' instead of 'protection of religion' (Ibn al-Ashur, 2011). After Ibn alAshur, presenters of this perception frequently quote the following Quran verse in their writings: 'No compulsion in matters of religion' (Al-Baqara 256). They also have a different kind of interpretation for the punishment of apostasy (Had al-riddah) and their arguments will be analysed briefly in the following topic.

Ibn al-Ashur emphasized in his book 'Maqasid al-shariah' on re-interpreting some words like freedom. For instance, the meaning of freedom which was proposed by him is different from freedom which was mentioned by traditional jurists. Ibn al-Ashur included freedom of thought, expression, belief and action in this particular terminology (Ibn al-Ashur, 2011). After Ibn al-Ashur, a number of scholars tried to expand the theory of freedom and paid special attention to freedom of belief. Rashid al-Ghanuchi had a deep discussion on how we could interpret the terminology 'Freedom of belief' (Ghanuchi, 1993). Furthermore, he has been playing a vital role in applying freedom of belief in Tunisia's context since the Arab spring although his approach is being criticized by few scholars.

\subsection{Misunderstood texts related to freedom of belief}

Number of contemporary scholars differ from classical scholars in understanding and interpreting the texts related to apostasy and its punishments. Both classic and modern scholars approach this critical issue with their political and historical factors. There were different opinions among traditional scholars themselves. Most of the traditional scholars argued that the death penalty is the punishment for apostasy regardless of the difference of opinions among them with regard to the waiting period while in incarceration to repent and accept Islam again. In contrast, a few other scholars refused and did not agree with particular punishment (Alwani, 2012).

Firstly, Modern scholars try to take a holistic view on freedom of belief by focusing on al-Quran verses. They frequently quote the following verses in order to strengthen their argument that Islam provides freedom of belief to whole human being:

"There is no compulsion in religion. The right way is indeed clearly distinct from error" (Al-Baqara 256)

"Say: (It is) the truth from the Lord of you (all). Then whosoever will, let him believe, and whosoever will, let him disbelieve. Lo! We have prepared for disbelievers Fire. Its tent enclosed them. If they ask for showers, they will be showered with water like to molten lead which burneth the faces. Calamitous the drink and ill the resting-place!" (Al-Kahf 29) 
"We have truly shown him the way; he may be thankful or unthankful" (Al-Insan 3)

"Clear proofs have indeed come to you from your Lord: so whoever sees, it is for his own good; and whoever is blind, it is to his own harm. And I am not a keeper over you” (Al-An'am 104)

"If they accept Islam, then indeed they follow the right way; and if they turn back, your duty (O Prophet) is only to deliver the message" (A'l Imran 20)

"And obey Allah and obey the Messenger; but if you turn away, the duty of Our Messenger is only to deliver the message clearly" (Al-Taghabun: 12; see also Al-Ma'idha 92)

Secondly, modern scholars refer to the Hadeeth where Prophet Muhammad emphasises the punishment for apostasy. There are number of narrations of the prophet that indicate the person who renounces Islam should be killed. Following two are among them:

"Whoever changes his religion, kill him" (Bukhari)

"The blood of a Muslim who confesses that none has the right to be worshipped but Allah and that I am His Apostle, cannot be shed except in three cases: In Qisas for murder, a married person who commits illegal sexual intercourse and the one who reverts from Islam (apostate) and leaves the Muslims." (Bukhari)

Most of the modern scholars argue that the background of above mentioned Hadeeth should be considered while interpreting. From a holistic view of the above mentioned and some other texts which are related to this issue, scholars come to the following conclusions:

1. Islam allows a person to embrace and practice any theology or religion which he believes in. He has the freedom and right to follow the instruction of his religion among the Muslims (Saeed, 2017). On the other hand, no one from the Muslims, even leader of the country, has the right to compel him to embrace Islam or leave his religion. Furthermore, Muslims should not disturb him during his prayers and while he is practicing his religious acts. The whole history from the prophetic era until the present would be the obvious evidence for this argument.

2. Al-Quran did not mention any punishment for apostasy in this world when describes about the people who returned back to their former religions and beliefs after embracing Islam. Following verse is a clear example for above mentioned argument: "And whoever of you reverts from his religion [to disbelief] and dies while he is a disbeliever - for those, their deeds have become worthless in this world and the Hereafter, and those are the companions of the Fire, they will abide therein eternally" (Al-Baqara 217). It is very interesting to make a note here that the writer Willi Heffening mentions in the Encyclopaedia of Islam: 'In the Quran the apostate is threatened with punishment in the next world only' (Encyclopaedia of Islam, vol. 3, p. 736).

3. Some scholars argue that the only apostates who did other crimes such as insubordination and plotting against the government, could be punished with death penalty. Committing crimes could be the only reason for which he deserves the punishment, and it has nothing to do with changing one's religion or belief (Nandwa, 2016). This was exactly what happened in fathhu Makka and some other occasions.

4. With a deep erudition into Madenian period, we could realize that some Jews changed their belief very frequently. Their intention was to make a mockery of purity of Islam (Raisuni, 2013). They tried to fabricate a public opinion that Islam is not a religion worth having. "Those who believe, then reject faith, then believe (again) and (again) reject faith, and go on increasing in unbelief, Allah will not forgive them nor guide them nor guide them on the way" (Al-Nisa 137)._The Quran did not ask the prophet to punish them even having mockery of purity of Islam.

5. The misconception regarding apostasy appears to have arisen from the people who joined the enemies of Muslims after becoming apostates. However, they were treated as enemies and were killed during the war; not for changing their religion, but for committing crimes and murders (Nandwa, 2016). The Quran points out a few cases where some people left Islam and merged with the opposition during war. It further guides the prophet and his companions on how to deal with this kind of people (Al-Nisa 88, 91).

6. Some other scholars deal with this issue in a different way. They argue that understanding the socio-political context of the prophetic period is very important. During that time apostasy was not considered as merely changing belief or faith. It was an act declaring war on the former (Alwani, 2012). According to this argument, apostasy was a political crime not a religious one. 
As we emphasised earlier, these interpretations provide a clear conclusion that Islam gives complete freedom to every person to follow and practice a religion he wishes. Moreover, it guides Muslims not to punish or insult the one who leaves and shifts to another religion.

\section{Discussion and Results}

\subsection{Applying 'freedom of belief' in contemporary world}

By understanding the above-mentioned paragraphs deeply, we will be able to measure the countries which provide religious freedom, and which restrict the freedom; which is the first and foremost objective of Islamic shariah.

Pew Research Centre which is located in USA conducted a research on religious freedom. Pew research categorized data from 18 published cross-national reliable sources and it referred to the sources only for welldocumented, specific facts, not for commentaries and opinions. The staff of the forum used extensive dataverification checks and inter -rated reliability assessments in order to come out with genuine and scientific results (Pew Research Centre, 2011). Following are main results of the research:

1. Research finds that seven out of the ten countries with the worst grades for government restrictions on religion are Islamic states (Pew Research, 2011).

2. Geographically, the Middle East/North Africa region boasted the largest proportion of countries -30 percent - where official restrictions on religion increased over the three-year period (Pew Research, 2011).

3. Seven of the ten countries with the highest - that is, worst - grades when it comes to government restrictions on religion were OIC countries. The other three were China, Burma and Eritrea (Pew Research, 2011).

4. In an index measuring official interference with religious practice, 18 out of 26 countries ( 69 percent) whose government "prohibits worship or religious practices of one or more religious groups as a general policy," were OIC members (Pew Research, 2011).

5. A grading of countries where conversion from one religion to another is restricted was also dominated by Islamic states, accounting for 25 out of 29 countries (Pew Research, 2011).

6. Taking the conversion issue a step further, among 13 countries where there were incidents of physical violence over conversions from one religion to another, 10 (77 percent) were Muslim majority countries (Pew Research, 2011).

7. A study conducted by Human Rights First and it documented more than 70 cases in 15 countries where the enforcement of blasphemy laws resulted in problems of various kinds since 2007. Of the 70 cases, only four were not in Muslim countries. By contrast, the vast majority of the cases documented in the report took place in Muslim majority countries and included lengthy prison terms and the imposition of the death penalty, as well as extrajudicial retribution such as mob attacks and killings (Human Rights First, 2012).

Number of contemporary Muslim scholars accept above mentioned facts and they keep on repeating that the Muslim majority countries should reduce religious restrictions and should provide religious freedom for their citizens (Alwani, 2012). Tariq Ramadan condemns the religious restrictions imposed by Muslim majority countries and he argues that all citizens have their freedom equally and the religious freedom should be guaranteed to the citizens (Ramadan, 2009). Rashid al-Ghanuchi criticizes the Muslim majority countries as well as the Islamic movements for their rigid approach to the religious freedom (Ghanuchi, 1993).

In summary, most of the Muslim majority countries neglect and ignore the first and foremost part of maqasid alshariah as elaborated by contemporary Islamic scholars, which is freedom of belief. On the other hand, number of non-Muslim countries offer freedom of belief or religious freedom to their citizens in satisfactory manner. Freedom of belief is one of the universal values that can be applied in every countries regardless of religions and ethnics (Ramadan, 1999). In some countries where Muslims are minority, freedom of belief is granted to the citizens in a healthy way.

\subsection{Freedom of belief in Sri Lanka: Constitution and its implementation}


Sri Lanka is an island with a population of 20 million consisting of a mixture of Sinhalese, Tamils, Muslims and others. The Sinhalese community is the majority while Tamils and Muslims are the minority respectively.

As far as the Sri Lankan constitution is concerned, there are two chapters which are closely related to religious freedom. Chapter 2 talks about Buddhism while chapter 3 speaks about fundamental rights. In the following paragraphs we will analyse the articles of these chapters which have specific provisions to safeguard the religious freedom in the country.

Chapter 03 includes some articles which provide religious freedom and rights to minority community:

Article 10: Every person is entitled to freedom of thought, conscience and religion, including the freedom to have or to adopt a religion or belief of his choice.

Article 12:

(1) All persons are equal before the law and are entitled to the equal protection of the law.

(2) No citizen shall be discriminated against on the grounds of race, religion, language, caste, sex, political opinion, place of birth or any such grounds

(3) No person shall, on the grounds of race, religion, language, caste, sex or any one such grounds, be subject to any disability, liability, restriction or condition with regard to access to shops, public restaurants, hotels, places of public entertainment and places of public worship of his own religion.

Article 14. (1) Every citizen is entitled to

(a) The freedom of speech and expression including publication;

(b) The freedom of peaceful assembly;

(c) The freedom of association;

(d) The freedom to form and join a trade union;

(e) The freedom, either by himself or in association with others, and either in public or in private, to manifest his religion or belief in worship, observance, practice or teaching;

(f) The freedom by himself or in association with others to enjoy and promote his own culture and to use his own language;

(g) The freedom to engage by himself or in association with others in any lawful occupation, profession, trade, business or enterprise;

(h) The freedom of movement and of choosing his residence within Sri Lanka; and

(i) The freedom to return to Sri Lanka

Above mentioned chapter with its articles illustrate that constitution of Sri Lanka provides special protection to minority religions against unequal treatment before the law and it ensures equal protection for them. Minority communities were given the freedom to draft the matters related to personal law like divorce, child custody, and inheritance according to their religious principles (Khan and Rahman, 2009). For instance, the minimum age level for marriage is 18 except for the Muslims. In day to day life activities the minority communities are given rights equal to the Buddhist majority.

In Sri Lanka, minority communities are given admission to state schools without any discrimination, they are provided employment in state sector, they have the right to build mosque or temple to conduct their worship, and they have the right of freedom to travel throughout the country (Godahewa, 2017). This indicates that Sri Lanka provides more religious freedom and accepts of religious freedom than many Muslim majority countries.

However, a number of complaints have been filed before the Supreme Court with regard to the violation of fundamental human rights (Roshani, 2016). Moreover, a report on a series of human rights violations is to be released by the Human Rights Commission as well. In comparison between Sri Lanka and Muslim majority countries, the former is very high and stable in religious freedom even though there were few unpleasant 
incidents reported against the minority communities in the past. For instance, Kandy riot against Muslims that took place on $29^{\text {th }}$ of February 2018 is one of the transparent examples for unethical violations. But the Sri Lankan government took necessary steps as much as to its possibility in order to curb and stop the riot. Nationwide state of emergency was imposed by the government to control the violations. Finally, Sri Lankan government arrested Amith Weerasingha who was alleged to be one of the masterminds of the communal unrest, along with 08 others. The rule of the law should be implemented to avoid these kinds of violations. Additionally, reasons for the breakdown of the rule of law should be identified and fulfilled (James, Craig, 2010).

There is a heated debate among political scholars regarding chapter 2 of the constitution. Following is the one and only article in this chapter:

The Republic of Sri Lanka shall give to Buddhism the foremost place and accordingly it shall be the duty of the State to protect and foster the Buddha Sasana, while assuring to all religions the rights granted by Articles 10 and $14(1)(\mathrm{e})$.

This preferential statement to Buddhism is highly controversial among scholars and researchers. Some argue that this article gives Buddhism the 'foremost place' and asks the government to protect it. The first meaning of that is, the minorities are second class citizens and they should be treated as second class not equal to majority Buddhist. Some activists argue that the only one solution for this kind of classification is to amend the constitution and make Sri Lanka as a 'Secular state' (Public Representations Committee on Constitutional Reform, 2016). They argue that secular state is a very positive one. History tells us that no religion or culture will automatically be protected merely by having state sponsorship. The best example would be Catholicism itself. As revealed by history, the decadence of the Catholic Church in Europe began with State sponsorship. Further they emphasize that a secular state does not mean being irreligious. But an equal freedom for people to pursue their spirituality and faith without the obstacle of a constitution that guarantees only one religion which can sometimes assault others.

On the other hand, some others emphasize that it does not recognize it as the state religion. Additionally, the constitution states that every person is "entitled to freedom of thought, conscience, and religion, including the freedom to have or to adopt a religion or belief of his choice." As we mentioned earlier, the constitution gives the priority and foremost place according to its overwhelming majority (76\%) (Public Representations Committee on Constitutional Reform, 2016). Meanwhile there are no obstacles, or discriminations against minorities except a few incidents reported here and there. Minorities have been given separate religious affairs departments and they are provided the freedom to conduct their religious education outside the school system. National holidays have been declared for the major religious festivals of other religious groups. Moreover, they argue that a non-religious state is a leftist idea. Buddhism is accepted as the major religion by tradition and accepted as a characteristic of democratic society. A country cannot exist without a religion.

In this controversial issue, it is very difficult to make changes in the constitution that Sri Lanka as a secular state and it would be an impossible task in the near future. According to modern activists, the most important thing is the community should be educated and trained to respect others and to live with religious tolerance and harmony. Finally, all academicians without any exception emphasize that the rule of law should be guaranteed as well as applied regardless of race, ethnicity and religion.

\section{Conclusion}

Freedom of belief and apostasy are two controversial terms which have made for heated debate among modern Muslim scholars. A number of them re-interpret the texts related to apostasy in a different way to classical scholars and they come to some conclusions. They argue that Islam considers freedom of belief as one of the universal values and it provides freedom of belief to all human beings. Further, they reiterate that Muslims, either in Muslim majority countries or Muslim minority countries, should contribute in guaranteeing freedom of belief to their fellow citizens. Unfortunately, several Muslim majority countries, especially Middle East countries, have strict rules and regulation as well as restriction on religious freedom. Moreover, official interference with religious practices and physical violence over conversions from one religion to another have been recorded there. It is clear that a number of Muslim minority countries are healthier than several Muslim majority countries in practicing freedom of belief, first segment of maqasid al-shariah. The Constitution of Sri Lanka and its application are transparent evidences for above mentioned argument. For instance, Sri Lankan government applied the rule of law without any religious discrimination during the Kandy riot that took place by imposing nationwide state of emergency and arresting the person who was alleged to be one of the mastermind of the riot along with other violators. 


\section{References}

Alwani, T. (2010). Afala yathadabbaruna al-Qur'an (pp. 62). Cairo: Dar al-Salam.

Alwani, T. (2012). Apostasy in Islam A Historical and scriptural analysis (pp. 03). USA: International Institute of Islamic Thought.

Atiya, J.D. (2008). Nahwa thaf ili maqasid al-shariah (pp. 98). USA: IIIT.

Jasir, A. (2008). Maqasid al-shariah a beginner's Guide (pp. 11). USA: The international institute of Islamic thought.

Jasir, A. (2007). Maqasid al-shariah as Philosophy of Islamic Law A systems approach (pp. 21). USA: The International Institute of Islamic Thought.

Deuraseh, N. (2012). New essential values of Daruriyyah of the objectives of Islamic Law, Journal Hadhari, 4(2), 107.

Ghanuchi, R. (1993). al-Huriya al-Aamma fi al-dawla al-Islamiya (pp. 44). Beirut: Markaz dirasath al-Wahda al-Arabiya.

Godahewa, N. (2017). Discrimination in Sri Lanka: The reality, Speech delivered at The $36^{\text {th }}$ Session of the UNHCR in Geneva On 27 September 2017.

Human Rights First. (2012). Blasphemy Laws Exposed: The Consequences of Criminalizing "Defamation of Religions".

Ibn al-Ashur, T. (2011). Maqasid al-shariah al-Islamiah (pp. 233). Cairo: Dar al-kithab al-Misri.

Ibn Rushd, W. (2000). Bidayah al-Mujthahid wa Nihaya al-Muqthasid (pp. 291). Dar al-Kutub al-Islamiyah.

James, Y, Craig, S. (2010). The Breakdown of the Rule of Law in Sri Lanka: An Overview (pp. 03). Sri Lanka Campaign for Peace and Justice.

Khan, B., Muhbubur R. (2009). Protection of Minorities: A South Asian Discourse (pp. 82). Dhaka: EURASIA NET.

Nandwa, W. (2016). Plurality and Religious Tolerance in Islam, European Scientific Journal, vol.12, No.32, 320

Pew Research Center's Forum on Religion and Public life, August, 2011.

Raisuni, A. (2013). Muhalarath fi maqasid al-shariah (pp. 62). 2nd Ed, Dar al-Kalima.

Raisuni, A. (2013). Al-fikr al-Islami wa kalayana al-siyasa al-muasira (pp. 90). $1^{\text {st }}$ Ed, Dar al-Kalima.

Ramadan, T. (2009). Islam, the West and the challenges of Modernity (pp. 76). $4^{\text {th }}$ Ed, Nigeria: The Islamic Foundation.

Ramadan, T. (1999). To be a European Muslim (pp.131). London: The Islamic Foundation.

Rane, H. (2013). The relevance of a maqasid Approach for political Islam post Arab Revolutions, Journal of Law and Religion, Vol.28, 490.

Report on public representations on Constitutional reform, 2016.

Rila, R. (2010). Al-wahyu al-Muhamadiyu (pp. 333). Al-Haia al-a'mma li kusur al-sakafa. 
Roshani, W. (2016). Confronting intolerance: Continued violations against religious minorities in Sri Lanka (pp. 08). Minority Rights Group International. 